\title{
The Infantile in the Psychoanalyst at Work
} Florence Guignard ${ }^{1}$

1

Psicanalista Titular com funções didáticas da Associação Psicanalítica Internacional (IPA), tendo pertencido às Sociedades Psicanalíticas da Suíça (SSPsa) e de Paris (SPP). Membro direto da IPA com funções de formação e de supervisão em Psicanálise de Crianças e Adolescentes à escala internacional. Presidiu à COCAP, da qual é membro destacado. Fundou a SEPEA (Société Europénne pour la Psychanalyse de l'Enfant e de l'Adolescent), à qual presidiu mais de uma vez. Membro do Conselho Editorial da revista L'Année Psychanalytique International. E-mail: florenceguignard@bluewin.ch

\section{ABSTRACT}

In order to define the Infantile and to examine its role in the analytic relationship, I considered this concept from both its developmental and structural status. I based my position on Freud's view of a double Unconscious, together container of the repressed and drive source. I also used jointly both Freudian models of the psychic apparatus, that I do not consider as exclusive from each other, but as complementary, although not always easy to put together. This led me to consider the peculiarities of the criteria for the termination of the analyst's personal analysis, and to try and describe the economic situation of repression in the psychoanalyst at work. By observing the impact of the Infantile-of-the-analysand upon the system PCS-CS of the psychoanalyst, I dealt with the odds and ends of the lack of representation and I tried to examine the situation and the future of the blind spots issued from such an impact.
KEYWORDS

Infantile

Analytic relationship Blind spots

\section{INTRODUCTION}

The handloom of the psychoanalyst invites her to weave the warp of her clinical activity together with the weft of her personal Metapsychology. I define it as personal because of the important unconscious part played in it of a knowledge available with all the odds and ends of its polysemy and its translations. This is so, that one day I discovered the urge to propose a new concept: "the Infantile". Believe me, to jump from the adjective to the noun took me much time and reflexion!

Because "the Infantile" is something that takes much place and can be cumbersome. It bothers nearly everybody, except the artists, because you cannot create anything without it, but even the artists find it difficult to live with. Still, there are also other exceptions, for instance those psychoanalysts who are treating children, in addition to their adult patients. This is probably the reason why they accept their own Infantile more easily than some other people who are viewing themselves so earnestly. Those child analysts know that without their own Infantile, they would really be embarrassed to experience and analyse their countertransference when they are confronted to the Infantile of their patients, including their adult patients.
Because I never leave my scientific ideal, I had to write a definition of it. That was in 1994 - printed in 1996 - and it went so:

\footnotetext{
"A strange historical-ahistorical conglomerate, the cradle of primal phantasies and sensory-motor experiences that are memorisable in the form of mnemic traces, the infantile is the psychic locus of the first and unrepresentable emergences of the instinctual drives. Of this initial event ("avant coup") we only know the representable derivatives in the form of infantile sexual theories on the one hand, and of mnemic traces on the other. A basic structure on the edges of our animality, a depositary and container for our instinctual drives, both libidinal and aggressive as well as epistemophilic, the infantile is the "flexible" blend of instinctual drive activity and structure which results in our being who we are and not someone else. Irreducible, unique and therefore universal, the infantile is thus the means by which our mind comes into being, through all the developments of its psychic bisexuality organised by the oedipal configuration.

On the frontiers of the unconscious (Ucs.) and of the preconscious system (Pcs.), the infantile is the most acute point of our affects, the locus of hope and cruelty, of courage and insouciance. It functions throughout life, according to a double spiral, both processual and signifying, and it
} 
can be found even in the most severe pathologies, provided one does not confuse these with the normal organisation of this infantile. And if, until we die, it continues to act simultaneously at the level both of the secondary oedipal processes and of primitive mechanisms, it is because this human infantile is heir to the extraordinary instinctual drive force whose fantastic deployment can be observed in the rhythm of the psychic development of the first stages of human life. And yet the instinctual drive aspect is not the only one involved in this attempt to define the infantile. The concept also covers what it carries along with it in terms of hallucinatory activity and the proto-symbolic, preforms that are emerging permanently in all our mental activities. Once the fixation points that fix our modes of being and having in sterile repetition have been unravelled thanks to analysis, these preforms will give back their vigour and underlying drive efficiency to more mature organisations, "setting the tone" of our personality as a subject in our usual adult mode of functioning."

Twenty-seven years later, I have neither found a more satisfactory definition, nor succeeded in take off any part of it and I keep on observing the Infantile in myself, in my patients, in my neighbourhood, in my colleagues.

Going further with my everyday weaving, I proposed a "genealogy of drives" in 1997, then a "classification of psychoanalytical concepts" according to their degree of complexity in 2001 . This allows me to locate the concept of Infantile at the border between the sexual drives and the Ego drives, and in the family of the "concepts of the third type", that try to describe "the-links-between-the-links" and are fit for the description of dynamic situations that develop in time and space. However, all this does not justify my urge to propose a new psychoanalytical concept, as we have already so many of them! In fact, I was bold enough to imagine that we could find it useful in our everyday monitoring of our counter-transferential movements.

\section{IN THE ANALYTICAL RELATIONSHIP}

We all know that the analyst's tool is her own psychic apparatus. Because the unconscious quality of it, this tool is remaining out of her conscious mind almost in totality.

Should we propose a metaphor of the analytical encounter, we could propose that of a shifting constellation of points of impact that generate tensions between two virtual spaces: the psychic space of the analyst and that of the analysand. Each of these spaces has, of course, its own organisation, but also common points, which I will place within two categories: (a) the oedipal organisation; and (b) the group mentality inherent to every human mind. In the analytic encounter, these points of impact will become functional. Under the fine conscious film of the therapeutic alliance, an encounter between the analysand's demand and the analyst's acceptance, the analysand will cathect these frontier spaces in an unconscious transferential mode belonging to the past, that is, to the transference. These spaces, which the analyst will have explored in his own personal analysis, are those of the double emergence of his countertransference and of his valency as an anaclitic object.

During the work of elaboration set in motion by the analytic treatment, the reorganisations due to the upheaval of repression and to the disappearance of certain cleavages will give way to new representations in the system PCS of one, or the other protagonists of the analytic couple. Such representations will inform them about the present state of the intrapsychic and interindividual conflicts of each of them - not only of the analysand.

Because we meet a coalescence of transferential and counter-transferential factors that have to do with the limits of the psychic competencies of both the analyst and the analysand, we shall meet much resistance in the analytic field, linked to unconscious representations. It will be the analyst's task to observe in herself the preconscious offspring of the latter.

In the course of each analytic encounter, a proper mode and rhythm of relation will soon be established, monitored by the analyst. When minimal disturbances of this mode and rhythm occur, they might not be noticed, just as it happens with minor troubles of the respiratory or cardiac movements. But when there are more important disturbances, one can observe a lack of representation. Classically, such an absence is attributed to a movement of transference. However, such an absence of representation can be observed in the analyst, in relation to her counter-transference. To define this lack of representation, I borrowed from Freud the expression of "blind spot", and I discovered that such a blind spot was experienced at an unconscious level as the loss of an internal, meaningful object - no matter if good or bad.

Normally, at the unconscious level of the mind, such a lack of representation will set in motion a process of figuration similar to that of the dream, and following the same lines of destiny: like the dream, this process of figuration will, most of the time, be instantaneously engulfed into repression; sometimes, though, it will provoke some confused images disowned of limits between the external and the internal world, between the Self and the Other, or else, between perception and hallucination. Rarely, a representation occurs in the double register of thing-representation and word-representation, for the sake of the analytic work of association and decondensation.

\section{ABOUT THE INFANTILE-IN-THE-PSYCHOANALYST}

I needed still much time and reading and writing to settle down my observations and confirm the 
fact that, yes, the Infantile was indeed the psychic space in which I was experiencing this temporary blindness, experienced as a loss of object.

As a student, Freud, Claparède, Piaget, then Melanie Klein, Winnicott, René Spitz, Serge Lebovici and René Diatkine were my masters. As a beginner in psychotherapy, I was confronted to children of various ages, who were waiting from me a help that I was not always able to bring them. This situation forced me to re-discover in myself the cathexis and the quality of attention, of sensorial capacities and of reminiscences of implicit memory arising from the first times of my existence. Later on, when I have also had adult patients, I could evaluate the importance of such a kind of listening to discover the Infantile of those patients as well.

Two parameters of the Freudian metapsychology were decisive to confirm the importance of the Infantile for the analytic functioning:

- The primordial value attributed by Freud to the infantile modes of thinking and of emotional cathexis, such as expressed in the sexual infantile theories, in the oedipal configuration of the psychic functioning, and in the infantile neurosis as a model for the transference neurosis;

- The concept of "drives", as a "border-concept", based on the Freudian discovery of a constant push of the drives, never exhausted by their satisfaction. Many thanks to the late André Green for having reminded this to all of us in such a mighty way!

Later on, I could observe how my colleagues who asked my help in supervision were surprised by the strength of reorganisation and transformation of any interpretative intervention addressed to the Infantile of their patients of all ages.

From then onwards, I oriented more specially my attention on the effects due to the Infantile of an adult person upon another adult person - more specifically, upon the analyst at work.

I shall briefly recall some characteristics of such a situation:

To begin with, I remind you that listening to our patients Infantile is not an easy task: "His Majesty the Baby" is egocentric, hedonistic, but also pertinent and clairvoyant about what we would prefer to "hide under the carpet" about our own intrapsychic and interpersonal conflicts. However, such a listening is also invigorating, as it is directed to our own infantile elements, specially those that arise in the present of the analytic situation as being the first expression of the drive that drives relentlessly.

The natural target of the patient's Infantile is of course its analogon: the analyst's Infantile. The meeting of the two will produce an unbounded excitement, due to the strength of the drive that it expresses. Hence, the analyst's defences are mobilised against what is usually designed as "the child's seduction addressed to the adult" - which is, by the way, the complementary version of what Jean Laplanche defines as "the seductive mother" of the beginning of the baby's life.

I would like to characterise here the analyst's defence when confronted to the meeting of his Infantile with that of his patient. According to my observation, this is a "blind spot", whose function is to hide the transfer-counter-transfer issue at that precise moment of the treatment, because this "blind spot" is containing the internal object - mostly a part-object or a part of the Self - projected into the analyst by the patient at that very moment.

As long as the analyst is not aware that $\mathrm{s} / \mathrm{he}$ is in a blind spot, s/he will behave herself - be it only in spirit - like this object of transference that $\mathrm{s} / \mathrm{he}$ represents without being conscious of it. A classic example of it is given by the feeling of anger an analyst might - silently — experience against a person of her patient's surroundings, going sometimes up to the impression that all her analysand's misfortunes are caused by this person... person that the analyst is precisely representing in the transference. From then on, as we know, such a discovery of the negative transference is only the beginning of a long and painful process.

The normal destiny of the excitement caused in a person by the impact of another person's Infantile is to diversify, to be linked by the Ego drives for a part of it, and to be repressed again for another part, so that the interpersonal relations would be protected against a too high drive excitement. The same should occur for the psychoanalyst at work... However, her situation is more complicated, as $\mathrm{s} / \mathrm{he}$ has to understand what is happening in such a blinding situation.

Linked to her inability to have a representation about what is going on, her feeling of a libidinal loss might bring the analyst to deny the negative, this loss that does not say its name and that challenges her at the level of her narcissistic identity feeling. S/he will then be tempted to give the analysand a "ready-to-wear" interpretation, what I name a "stopper-interpretation". Amongst those, let us mention:

(1) Recourse to the analysand's personal history is used abundantly, particularly when one or several severe traumas have occurred in the course of this history.

(2) Recourse to psychoanalytic theory: Each one of us is familiar with the temptation of such recourse, which is aimed at circumventing a distressing element of the emotional field in the analytic relationship. The blind spot aroused by the impact on the analyst of the infantile-in-the-analysand sometimes acts as a strong spur for the analyst to have recourse to psychoanalytic theory as a stopper-representation.

(3) Recourse to making the analysand feeling guilty should be an ultimate system of alert for analysts in search of their blind spots. Like a bad student, the analysand 
refuses to listen to an interpretation that is nonetheless deemed to be clear by the analyst who, in addition, has repeated it several times without success. Sometimes it is the analysand who best expresses the situation, when he complains, at this precise moment, that he has "fallen into a void", because he no longer feels contained or supported by the analytic situation. The analyst's ignorance of his own blind spots does not allow the underlying drive excitation, arising from the encounter between two Infantiles, to transform and organise itself at a representable level of psychic conflictuality. The analytic material thus remains in limbo, unrepresentable, and therefore inaccessible to the secondarised defensive reorganisations in the order of repression.

This situation is not only a waste of time for the two protagonists, as well as of the analysand's finances - which is not insignificant - , but above all we witness an increase of guilt in the analysand who, at the unconscious level of his infantile, feels guilty for the analyst's blindness, just as, in real life, children always feel unconsciously guilty for the splits and conflicts that occur in their parents.

The repeated reference to an interpretation that has not reached the patient should induce the psychoanalyst quickly to undertake an exploration of his own infantile omnipotence, that is, to try to examine what, in his listening, resists the free functioning of his projective identification with the psychic state of the patient.

Whenever the analyst is unaware of his blind spots, the drive excitation arising from the encounter of the two Infantiles can only increase. In the treatment of children, it is motor agitation that will dominate the clinical picture; with adults we will be confronted with an erotisation of the transference which masks an unanalysed negative transference.

\section{THE STATUS OF REPRESSION}

\section{IN THE PSYCHOANALYST}

In my opinion, the psychoanalyst is in a very peculiar situation concerning the criteria of termination of his own analysis and the post-analytical reorganisation of repression of her Infantile, confronted to the demands of her professional functioning.

Let us consider that the personal psychoanalysis of the analyst allows her to avoid the use of projective defences with her patient and to rid of disabling inhibition of her associative capacity to think. However, this does not explicit the situation of her Infantile in her psychic functioning during an analytic session.

I am not alluding so much to the elements of her infantile neurosis - supposedly dissolved by her personal analysis. I am mainly speaking of the perpetual emergence of her Infantile that is constituting the lifelong matrix of the passage of the drive organisation to the psychic organisation and thus, keeps giving the density and complexity of her object-relations and identifications, as well as the originality of her mode of thinking.

Now, from the point of view of the analyst's psychic economy, one has to understand that her analytic functioning obliges herself to fight against the normal repression that occurs in every patient at the end of her psychoanalytic treatment.

This brings us back to the question raised by Freud of terminable or interminable analysis:

\begin{abstract}
"It seems that a number of analysts learn to make use of defensive mechanisms which allow them to divert the implications and demands of analysis from themselves (probably by directing them on to other people), so that they themselves remain as they are and are able to withdraw from the critical and corrective influence of analysis.” (Freud, 1993, p. 249)
\end{abstract}

And, a little further, on he adds:

\begin{abstract}
"It would not be surprising if the effect of a constant preoccupation with all the repressed material which struggles for freedom in the human mind were to stir up in the analyst as well all the instinctual demands which he is otherwise able to keep under suppression." (ibid.)
\end{abstract}

\section{THE TRAPS OF THE INFANTILE FOR THE PSYCHOANALYST AT WORK}

Now, as we have seen, the impact of the infantile of one subject on the Pcs. of another subject produces excitation that both carries and generates oedipal impulses and primal phantasies. Consequently, at least in neurotic/normal functioning, this excitation, and everything that goes with it, is usually subjected to repression, whose nature and quality will govern the forms taken by the return of the repressed, ranging from act to thought. We may thus ask ourselves how and, above all, at what price, the practising psychoanalyst manages to escape this normal functioning.

Freud noted two exceptions to this rule of "normal" psychic functioning: the state of being in love and the transference relationship. With the advent of the crucial works of Winnicott (1969) and then of Bion (1962,1979), two others were added: the "ordinary illness of the mother" (Winnicott) and the "capacity for reverie" (Bion).

Now, owing to the work of the countertransference, analytic listening requires from the psychoanalyst to maintain artificially, outside the normal process of repression, the impact of the excitation produced on her system Pcs. by the infantile-in-his-analysand. The study of the Infantile thus leads us to designate the countertransference relationship as a fifth exception to normal psychic functioning.

Such a professional peculiarity about the status of our Infantile is playing a permanent role in our 
capacity to listen. It also influences our activity of interpretation, because of the risk of collusion of the two Infantiles.

For instance, when we are ready to interpret the patient's projection upon us of a harsh and rigid post-oedipal parental Superego, let us not forget that, under such a manifest aspect of the transference, another psychic movement is also active: the defensive and omnipotent functioning of a weak Ego, whose infantile helplessness is projected into the analyst and is denied by means of its opposite: the infantile omnipotence.

Now, this hidden defence will create a situation of narcissistic seduction on the analyst's Infantile. Becoming conscious of such an ambiguous relationship between the two Infantiles is the only way, for the analyst, to choose her intervention, possibly her interpretation, and, maybe, to bring into the analytic field a more protective and developmental aspect of the Superego.

Unless it is detected, the exciting point giving rise to a blind spot tends to be repressed before having been analysed, and thus it might well reappear either in acting in the counter-transference, or in acting out of the analytic situation, in the personal life, or even in somatisations of the psychoanalyst.

\section{CONCLUSION}

As being the work of "the negative" and the expression, for the analyst, of the denial of a fantasy of seduction by the infantile omnipotence of the analysand, the blind spot will, if one does not trace it, constitute a narcissistic defence that aims at break the link in the analytic pair.

At this point, the analyst's destiny - to fight constantly against her normal movements of repression - might well have some advantages: because $\mathrm{s} / \mathrm{he}$ will be obliged to remember the identity poverty hidden by the omnipotence, s/he will perhaps find more easily the authentic ground on which it will be possible to re-start an analytic communication.

However, let us not forget that the Infantile is the only part of the Self that is flexible enough to undertake psychic transformations, resilient enough to learn from experience, loving enough to forgive, passionate enough to sacrifice itself, bold enough to take up impossible challenges, young enough to hope.

This is why the work of super or inter-vision, in one-to-one, or in a small group, provides many advantages from a better understanding of the destiny of our Infantile as psychoanalysts. It becomes clear, at that point, that it is a matter of a necessary disease for our analytic functioning, because a practitioner who would not fall into any blind spot would indeed stay aside the analytic field and the transfer-counter-transfer situation.

\section{RESUMO}

A fim de definir o Infantil e examinar o seu papel na relação analítica, considerei este conceito tanto numa perspetiva de desenvolvimento como numa perspetiva estrutural. A minha posição é baseada na visão de Freud de um duplo Inconsciente, contentor simultâneo do recalcamento e das pulsões. Também utilizei conjuntamente os dois modelos freudianos do aparelho psíquico, que não considero exclusivos um do outro, mas complementares, embora nem sempre fáceis de integrar. Seguidamente, considerei as peculiaridades dos critérios para o término da análise pessoal do analista e procurei descrever a situação económica do recalcamento do psicanalista no trabalho analítico. Ao observar o impacto do Infantil do analisando sobre o sistema PCS-CS do psicanalista, refleti nas dificuldades associadas à falta de representação e tentei examinar no contexto da situação analítica os pontos cegos decorrentes de tal impacto.

\section{PALAVRAS-CHAVE}

Infantil, relação analítica, pontos cegos.

\section{BIBLIOGRAPHY}

Bion, W. R. (1962). A theory of Thinking. International fournal of Psychoanalysis 43, 4-5.

Bion, W. R. (1979). Aux sources de l'expérience. P.U.F., 1979. (Trabalho original de 1962).

Freud, S. (1964). Analysis terminable and interminable. Em The Standard Edition of the Complete Psychological Works of Sigmund Freud. The Hogarth Press. (Trabalho original publicado em 1937).

Freud, S. (1975). Die endliche und die unendliche Analyse, Schriften zur Behandlungstechnik, (pp. 388-389). S. Fischer Verlag. (Trabalho original publicado em1937.)

Freud, S. (1985). Analyse avec fin, analyse sans fin, Résultats, idées, problèmes (vol. II, pp. 231-268). P.U.F. (Trabalho original publicado em 1937.)

Freud, S. (1993). L'analyse avec fin et l'analyse sans fin. Bayard. (Trabalho original publicado em 1937.)

Laplanche, J. (1986). De la théorie de la séduction restreinte à la théorie de la séduction généralisée. Fournal de la Psychanalyse de l'Enfant 25, 7-25.

Winnicott, D.W. (1969). La capacité d'être seul. Em De la pédiatrie à la psychanalyse (pp. 205-213). Payot. (Trabalho original publicado em 1958.) 